\title{
Organization of the lophophoral nervous system in the cyclostome bryozoans confirms the relationship of the Bryozoa and Brachiozoa
}

\author{
E.N. Temereva, I.A. Kosevich \\ Dept. Invertebrate Zoology, Biological Faculty, Moscow State University, Moscow, 119991 Russia. \\ E-mail: temereva@mail.ru
}

\begin{abstract}
The phylogeny of bryozoans is ambiguous and apparently cannot be resolved by molecular methods alone. Morphological data from previously unstudied species may help establishing relationships between the main groups of the Bryozoa and may help to clarify bryozoan phylogeny. The Cyclostomata is the least studied group of bryozoans. The nervous system of cyclostomes has not been described utilising modern methods until this year. The recent data, which were obtained from two different cyclostome species, revealed some lophophoral nerves may be compared with the lophophore nervous elements in other lophophorates. In this paper, new data on organization of the nervous system in cyclostome Cinctipora elegans and Crisia eburnea are discussed in frame of the problem of the lophophorates monophyly. In both cyclostome species, the cerebral ganglion gives rise to circumoral nerve ring and outer nerve ring. The circumoral nerve ring gives rise to frontal neurite bundles of tentacles and intertentacular neurite bundles, which extend between tentacles at their base. Each tentacle is innervated by six (in Crisia eburnea) or four (in Cinctipora elegans) longitudinal neurite bundles. In addition to these intraepithelial neurite bundles, the peritoneal neurites pass along the lateral sides of each tentacle between peritoneal lining and extracellular matrix. The outer nerve ring extends along the outer surface of the lophophore at the base of tentacles. The outer nerve ring was previously described only in ctenostome Amathia gracilis. The outer nerve ring may be regarded homologous to the terntacular nerve ring in phoronids and lower brachial nerve in brachiopods. The similarities in the innervation of the lophophore and tentacles in all lophophorates are consistent with the view that the Bryozoa and Brachiozoa are closely related.

How to cite this article: Temereva E.N., Kosevich I.A. 2018. Organization of the lophophoral nervous system in the cyclostome bryozoans confirms the relationship of the Bryozoa and Brachiozoa // Invert. Zool. Vol.15. No.4. P.366-372. doi: 10.15298/invertzool.15.4.05
\end{abstract}

KEY WORDS: cerebral ganglion, tentacles, lophophore, lophophorates, evolution, phylogeny.

\section{Организация нервной системы лофофора у круглоротых мшанок подтверждает родство Bryozoa и Brachiozoa}

\author{
Е.Н. Темерева, И.А. Косевич
}

Dept. Invertebrate Zoology, Biological faculty, Moscow State University, Moscow, 119991 Russia. E-mail: temereva@mail.ru 
РЕЗЮМЕ: Филогения мшанок не может считаться однозначно решенной и не может быть реконструирована лишь на основе молекулярно-генетических данных. Результаты, полученные на ранее не изученных видах из разных групп, позволят сделать морфологический анализ более полным, что в свою очередь станет весомым вкладом в определение филогении и эволюции мшанок и родственных групп. Циклостоматные мшанки (Cyclostomata) являются группой, которая чрезвычайно плохо исследована современными методами. Вплоть до настоящего времени в научной литературе не было никаких детальных сведений об организации нервной системы у циклостомат. В настоящей работе новые результаты, опубликованные в научной литературе по организации нервной системы у двух циклостоматных мшанок (Cinctipora elegans и Crisia eburnean), обсуждены в свете проблемы монофилии лофофорат. У обоих исследованных видов круглоротых мшанок церебральный ганглий дает начало околоротовому и внешнему нервным кольцам. Околоротовое нервное кольцо дает начало нервным трактам щупалец: фронтальным и межщупальцевым. В каждом щупальце проходит шесть (у Crisia eburnea) или четыре (у Cinctipora elegans) продольных нервных тракта. В дополнение к главным интраэпителиальным нервным трактам щупальца иннервируются перитонеальными нервными тяжами, которых проходят вдоль латеральных сторон каждого щупальца между целомической выстилкой и слоем внеклеточного матрикса. Внешнее нервное кольцо проходит вдоль внешней стороны лофофора в основании щупалец и не принимает участия в иннервации щупалец. Внешнее нервное кольцо может рассматриваться как гомолог щупальцевому нервному кольцу у форонид и внешнему брахиальному нерву у брахиопод. Наличие в лофофоре сходных (гомологичных) главных нервных трактов, наличие межщупальцевых нервов, от которых берут начало нервы соседних щупалец, а так же сходная иннервация щупалец (в том числе, наличие необычных перитонеальных нейритов) позволяет предполагать гомологию лофофора у всех трех групп лофофорат: форонид, брахиопод и мшанок. Эти данные согласуются с идеей о близком родстве Bryozoa и Brachiozoa и позволяют рассматривать мшанок в составе группы Lophophorata.

Как цитировать эту статью: Temereva E.N., Kosevich I.A. 2018. Organization of the lophophoral nervous system in the cyclostome bryozoans confirms the relationship of the Bryozoa and Brachiozoa // Invert. Zool. Vol.15. No.4. P.366-372. doi: 10.15298/ invertzool.15.4.05

КЛЮЧЕВЫЕ СЛОВА: церебральный ганглий, щупальца, лофофор, лофофораты, эволюция, филогения.

\section{Introduction}

Cyclostomes are marine calcified bryozoans, composing a single group of recent Stenolaemates. According to the modern view on phylogeny, the phylum Bryozoa includes two sister groups: Phylactolaemata and Stenolaemata + Gymlnolaemata.

All bryozoans are colonial animals. In colony, each individual, which is called zooid, consists of two parts: cystid and polypide. Cystid is the firm portion of zooid, whereas polypide is the soft part. Polypide bears lophophore with tentacles. The lophophore is a special organ, which bears ciliated tentacles utilized for capturing food particles. The shape of the lophophore differs in specimens from different groups and varies from oval to horseshoe (Schwaha, Wanninger, 2015).

The presence of the lophophore is traditionally considered as morphological peculiarity of the lophophorates including three phyla of in- 
vertebrates: Phoronida, Brachiopoda, and Bryozoa (Hyman, 1959; Emig, 1976). In recent view on phylogeny, bryozoans are regarded as separated group, not relative with the other lophophorates: phoronids and brachiopods that form united group called Brachiozoa (Kocot $e t$ al., 2017). The organization of the lophophore nervous system may be used for morphological analysis in comparative study of lophophorates phylogeny (Temereva, 2017). New data on organization of the nervous system in poorly studied groups contribute into complex morphological analysis that may help clarifing the phylogeny of bryozoans.

Cyclostome bryozoans are the poorest studied by modern methods. There are two modern papers with description of the nervous system in cyclostome Cinctipora elegans (Schwaha et al., 2018) and Crisia eburnea (Temereva, Kosevich, 2018). In this report, new data on organization of the nervous system in cyclostome bryozoans are discussed in the light of problem of the lophophorates monophyly.

\section{Results and discussion}

Detailed descriptions of neuroanatomy in two cyclostome bryozoans are given in recent papers (Schwaha et al., 2018; Temereva, Kosevich, 2018). Herein, the description of the nervous system is done in several main traits. The main element of the nervous system is the cerebral ganglion. In C. elegans, the cerebral ganglion has complex structure and is associated with two lateral ganglia. In C. eburnea, the cerebral ganglion has wide proximal concavity and small inner cavity, both filled with microvilli and cilia.

Several main nerve tracts project from the cerebral ganglion and innervate the lophophore. The circumoral nerve ring runs around the pharynx and form the inner nerve ring of the lophophore. The circumoral nerve ring contributes into innervation of tentacles and gives rise to the frontal and intertentacular nerves. In C. ebur$n e a$, the laterofrontal and lateroabfrontal nerves of tentacle arise from intertentacular nerves. Abfrontal tentacular nerves originate from the left or right lateroabfrontal tentacular nerves. In C. elegans, the lateroabfrontal nerves of tentacle are absent and the abfrontal tentacular nerves originate directly from circumoral nerve ring or from intertentacular nerves. Thus, in C. ebur$n e a$, each tentacle is innervated by six neurite bundles, whereas in C. elegans, each tentacle is innervated by four neurite bundles. In both species, in addition to these intraepithelial neurite bundles, the peritoneal neurites pass along lateral sides of each tentacle between peritoneal lining and extracellular matrix. In C. elegans, peritoneal neurites exhibit immunoreactivity against acetylated alpha-tubulin, whereas these neurites were not detected by staining against acetylated alpha-tubulin in C. eburnea, but were found by transmission electron microscopy method.

The pharyngeal nerve ring is described in $C$. eburnea and is absent in C. elegans. In $C$. eburnea, the pharyngeal nerve ring is projected form the lower portion of the cerebral ganglion and form broad nerve net around the vestibulum and pharynx. The pharyngeal nerve ring innervates the muscles of pharynx and gives rise to two lateral nerves, extending along the descending branch of the digestive tract. In C. elegans, two medio-lateral visceral neurite bundles and one medio-visceral neurite bundle extending along the descending branch of the digestive tract arise from the lateral ganglia.

The outer nerve ring is discovered in both studied cyclostome species. This nerve ring runs along the outer side of the lophophore at the base of tentacles. The outer nerve ring does not contribute into innervation of tentacles.

The lophophore is the unique characteristic of all lophophorates. As traditionally defined, the lophophore is "a tentaculated extension of the mesosome (and its cavity — the mesocoelom) that embraces the mouth, but not the anus, and its main functions are feeding, respiratory and protective" (Hyman, 1959; Emig, 1976). For the reason of the lophophore presence, three phyla of invertebrates are traditionally regarded as lophophorates: phoronids, bryozoans, and brachiopods. The monophyly of the lophophorates, however, is not supported by 


\title{
Phoronida
}

\author{
Brachiopoda
}

Bryozoa

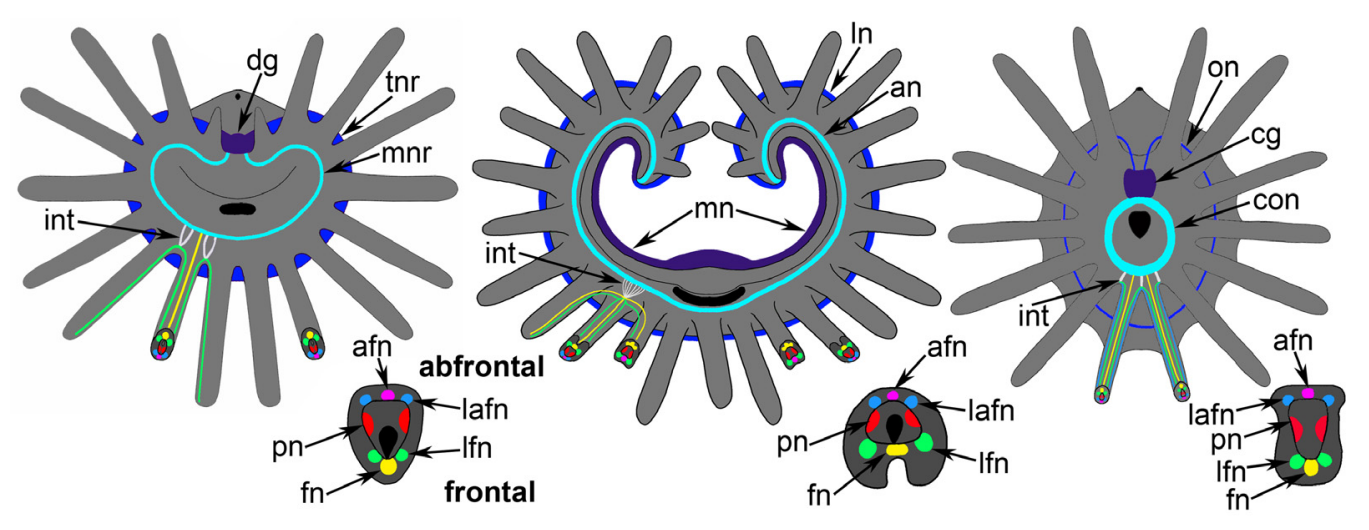

Fig. 1. Schemes of the lophophore and tentacles innervation in the lophophorates. A — phoronids (based on Temereva, Tsitrin, 2014; Temereva, 2017); B — brachiopods (based on Temereva, Tsitrin, 2015; Temereva, Kuzmina, 2017); C — bryozoans (based on Temereva, Kosevich, 2016, 2018; Schwaha et al., 2018). Homologous elements are shown by similar color.

Abbreviations: afn — abfrontal tentacular nerve; an — accessory brachial nerve; cg — cerebral ganglion; con circumoral nerve ring; dg — dorsal ganglion; fn — frontal tentacular nerve; int — intertentacular nerve; lafn — lateroabfrontal tentacular nerve; lfn - laterofrontal tentacular nerve; ln - lower brachial nerve; mn — main brachial nerve; mnr - minor nerve ring; pn - peritoneal neurite; tnr - tentacular main nerve ring.

Рис. 1. Схемы иннервации лофофора и щупалец у лофофорат. А — лофофор форониды (по Теmereva, Tsitrin, 2014; Temereva, 2017); В - лофофор брахиоподы (по Temereva, Tsitrin, 2015; Temereva, Kuzmina, 2017); C — лофофор мшанки (по Temereva, Kosevich, 2016, 2018; Schwaha et al., 2018). Гомологические элементы показаны одинаковым цветом.

Обозначения: afn — абфронатльный нерв щупальца; an — добавочный брахиальный нерв; cg — церебральный ганглий; con - циркуморальное нервное кольцо; $\mathrm{dg}$ - дорсальный ганглий; $\mathrm{fn}$ — фронтальный щупальцевый нерв; int - межщупальцевый нерв; lafn - латероабфронтальный щупальцевый нерв; lfn - латерофронтальный щупальцевый нерв; $\ln$ — нижний брахиальный нерв; mn - главный брахиальный нерв; mnr - малое (внутреннее) нервное кольцо; pn - перитонеальные нервы щупалец; thr — щупальцевое нервное кольцо.

recent molecular results, according to which bryozoans (the Bryozoa) form a separate clade that is unrelated to phoronids or brachiopods, which together form a united clade called the Brachiozoa (Kocot et al., 2017). In some papers, devoted to molecular phylogeny of Bilateria, bryozoans are regarded as the closest relatives of entoprocts: both groups together with cycliophorans are united into clade Polyzoa (Hejnol at el., 2009; Kocot et al., 2017). At the same time, the general morphology and innervation of tentacle apparatus significantly differ in bryozoans and entoprocts (Borisanova et al., 2018).

Because the lophophore is the common morphological feature in all lophophorates, the study of the lophophore may help clarify the relationship of the Bryozoa and Brachiozoa.
The innervation of the lophophore has been studied by modern methods in one adult phoronid (Temereva, 2017a), two brachiopods (Temereva, Tsitrin, 2015; Temereva, Kuzmina, 2016), and many bryozoans from different groups (Weber et al., 2014; Gruhl, Schwaha, 2015; Shunkina et al., 2015; Temereva, Kosevich, 2016; Ambros et al., 2017; Schwaha et al., 2018). The homology of lophophoral nerves remains to be assessed by molecular and embryological approaches. In the present morphological and ultrastructural study, we assumed that the nerve elements of the lophophore are homologous if their location with respect to the tentacles and mouth are similar (Fig. 1).

All lophophorates have a nerve ring that extends along the abfrontal base of the tentacles. In phoronids it is the tentacular nerve ring 
(Silen, 1954; Temereva, Tsitrin, 2014; Temereva, 2017a), the lower brachial nerve in brachiopods (Temereva, Malakhov, 2015; Temereva, Tsitrin, 2015; Temereva, Kuzmina, 2016), and the outer nerve ring in bryozoans (Temereva, Kosevich, 2016, 2018; Schwaha et al., 2018). In bryozoans, the outer nerve ring was described by modern methods in ctenostomes (Temereva, Kosevich, 2016) and cyclostomes (Schwaha et al., 2018; Temereva, Kosevich, 2018), whereas numerous cheilostomes and phylactolaemates seem to lack the outer nerve ring. This result has to be confirmed by investigation of the new species from these groups.

A nerve centre located behind the mouth is also known for all lophophorates, and is called the dorsal ganglion in phoronids and the cerebral ganglion in bryozoans. In brachiopods, this nerve centre is represented by an extensive main brachial nerve.

The third nerve element, which is common for all lophophorates, is the inner nerve ring passing along the frontal base of the tentacles. This nerve, the inner nerve ring, has been found in Phoronis ovalis (Temereva, 2017a) and in juveniles of Phoronopsis harmeri (Temereva, Tsitrin, 2014). The inner nerve is called the accessory brachial nerve in brachiopods and the circumoral nerve ring in bryozoans. Thus, all lophophorates have at least three nerve elements that may be regarded as homologous (Fig. 1).

The innervation of tentacles is also very similar in all lophophorates (Fig. 1). In general, each tentacle has six main nerves: one frontal, two laterofrontal, one abfrontal, and two lateroabfrontal. Certain species from all three groups show deviations from this scheme. Adult phoronids, for example, lack prominent lateroabfrontal nerves and have only four nerves in each tentacle, whereas juvenile phoronids have six nerves (Temereva, Tsitrin, 2014; Temereva, 2017a). At the same time, in adult phoronids, lateroabfrontal neurite bundles exhibit serotonin-like immunoreactivity, whereas abfrontal neurite bundles do not exhibit such reactivity (Temereva, 2017a). Thus, lateroabfrontal neurite bundles can be regarded as specific nerves of tenta- cles. Among the brachiopods studied to date, Lingula anatina lacks lateroabfrontal nerves, whereas Hemithiris psittacea has six nerves in each outer tentacle (Temereva, Tsitrin, 2015; Temereva, Kuzmina, 2017). Among bryozoans, cyclostome C. eburnea and phylactolaemates have six nerves in each tentacle, whereas cyclostome $C$. elegans, some ctenostomes, and gymnolaemates have four nerves; but other ctenostomes have two nerves in each tentacle (Schwaha, Wood, 2011; Weber et al., 2014; Gruhl, Schwaha, 2015; Shunkina et al., 2015; Temereva, Kosevich, 2016, 2018; Ambros et al., 2017). The difference in number of tentacular nerves in two cyclostome species may be explained by overlook. Thus, in paper of Schwaha and coauthors (2018), lateroabfrontal neurite bundles are evident in figures $14 \mathrm{a}$ and $14 \mathrm{~b}$, but they are not marked in 3D-reconstruction. Accordingly to these pictures, in C. elegans each intarentacular nerve gives rise to four neurite bundles that penetrate adjacent tentacles: two laterofrontal and two lateroabfrontal. The same variant of the tentacle innervation was described in cyclostome $C$. eburnea.

The lophophorates differ in origin of tentacular nerves. In bryozoans, all tentacular nerves originate from the circumoral nerve ring, whereas the outer nerve ring does not contribute into tentacles innervation. In all bryozoans, which have the outer nerve ring, the latter consists of a few numbers of neurites and seems to be reduced in comparison with the tentacular nerve ring in phoronids and the lower brachial nerve in brachiopods. In adult Phoronis ovalis, frontal and laterofrontal tentacular nerves originate from the inner nerve ring, but abfrontal and lateroabfrontal tentacular nerves start from the tentacular nerve ring. Other adult phoronids lack the inner nerve ring and tentacles are completely innervated by the tentacular nerve ring (Silén, 1954). In juvenile Phoronopsis harmeri, inner nerve ring gives rise to frontal tentacular nerves, but not to laterofrontal (Temereva, Tsitrin, 2015). In brachiopods, two different ways of innervation of tentacles were discovered. In Lingula anatina, frontal and lateroabfrontal nerves of inner and outer tentacles originate from the 
accessory brachial nerve, whereas in Hemithiris psittacea, frontal and laterofrontal tentacular nerves originate from the main brachial nerve (Temereva, Tsitrin, 2015; Temereva, Kuzmina, 2017). In both brachiopod species abfrontal and lateroabfrontal tentacular nerves arise from the lower brachial nerve. Thus, in bryozoans, there is a reduction of the outer nerve ring role (participation) in innervation of tentacles in comparison with phoronids and brachiopods. This reduction may correlate with reduction of body size of each zooid. In contrast, in phoronids and brachiopods there is a reduction of the inner nerve ring role in the innervation of tentacles.

In all lophophorates, there are intertentacular nerves, which give rise to tentacular nerves penetrating into adjacent tentacles (Fig. 1). Intertentacular nerves arise from the inner nerve ring of the lophophore. In phoronid Phoronis ovalis, each intertentacular nerve is represented by two neurite bundles, which fuse each other and give rise to nerves into adjacent tentacles. In brachiopod Lingula anatina, each intertentacular nerve is represented by thick bundle of numerous thin neurites. In most bryozoans, the intertentacular nerve is a thick single nerve.

In addition to intraepidermal nerves, each tentacle in all lophophorates is innervated by peritoneal neurites. These neurites were described in adult phoronids (Temereva, 2015, 2017), in brachiopods (Temereva, Tsitrin, 2015; Temereva, Kuzmina, 2017; Temereva, 2017b), and in bryozoans (Weber et al., 2014; Tamberg, Shunatova, 2017). In all lophophorates (phoronids, brachiopods, and bryozoans), peritoneal neurites were initially described by method of transmission electron microscopy (Fernandez et al., 1996; James, 1997; Mukai et al., 1997). Peritoneal neurites have specific ultrastructure: these are relatively large projections with electron-lucent cytoplasm and thick longitudinal microtubules. In brachiopods, peritoneal neurites originate from specific cells of coelomic lining located at the base of each tentacle. In brachiopod Hemitheris psittacea, these cells and their projections (peritoneal neurites) exhibit strong immunoreactivity against acetylated alpha-tubulin (Temereva, Kuzmina,
2017). In bryozoans, the same immunoreactivity of peritoneal neurites was first described in C. elegans (Schwaha et al., 2018). In phoronids studied to date, peritoneal neurites do not exhibit immunoreactivity against acetylated alphatubulin. The presence of such unusual structures as peritoneal neurites was detected only in lophophorets: phoronids, brachiopods, and bryozoans, but not in any other animals with tentacles.

Comparative analysis revealed the presence of homologous nerves of the lophophore in all lophophorates. Until this year, the outer nerve ring was described in only ctenostome bryozoan Amathia gracilis (Temereva, Kosevich, 2016). New studies of this year, allowed to insist that the outer nerve ring is characteristic of the lophophore nervous system of all bryozoans. This statement needs new data from different species from all groups of bryozoans. Presence of similar main nerves in the lophophore, presence of intertentacular nerves that innervate adjacent tentacles, and great similarity in innervation of tentacles in phoronids, brachiopods, and bryozoans make the lophophore unique organ, which is peculiarity of the lophophorates. Thus, bryozoans may be regarded as lophophorates and as the closest relatives of Brachiozoa.

\section{Acknowledgements}

This work was done with support from the Russian Foundation for Basic Research (comparative analysis - \#17-04-00586) and from the Russian Science Foundation (processing of the paper-\#18-14-00082; preparation of figures 14-50-00029).

\section{References}

Ambros M., Wanninger A., Schwaha T.F. 2017. Neuroanatomy of Hyalinella punctata: Common patterns and new characters in phylactolaemate bryozoans // J. Morphol. Vol.279. P.242-258.

Borisanova A.O., Malakhov V.V., Temereva E.N. 2018 (in press). Does the organization of the nervous system in Entoprocta confirm a close relationship of entoprocts and bryozoans? // Front. Zool.

Emig C.C. 1976. Le lophophore-structure significative des Lophophorates (Brachiopodes, Bryozoaires, 
Phoronidiens) // Zool. Scr. Vol.5. No.1-4. P.133137.

Fernández I., Pardos F., Benito J., Roldan C. 1996. Ultrastructural observation on the phoronid nervous system // J. Morph. Vol.230. P.265-281.

Gruhl A., Schwaha T. 2015. Bryozoa (Ectoprocta) // A. Schmidt-Rhaesa, S. Harzsch, G. Purschke (eds.). Structure and Evolution of Invertebrate Nervous Systems. London, UK: Oxford University Press UK. p.325340.

Hejnol A., Obst M., Stamatakis A., Ott M., Rouse G.W., Edgecombe G.D. 2009. Assessing the root of bilaterian animals with scalable phylogenomic methods // Proc. Biol. Sci. Vol.276. P.4261-4270.

Hyman L.H. 1959. The lophophorate coelomates - phylum Brachiopoda // L.H. Hyman (ed.). The Invertebrates: Smaller Coelomate Groups: Chaetognatha, Hemichordata, Pognophora, Phoronida, Ectoprocta, Brachipoda, Sipunculida: the Coelomate Bilateria. Vol.5. New York: McGraw-Hill. P.516-609.

James M. 1997. Brachiopoda: Internal anatomy, Embryology, and Development // F.W. Harrison, R.M. Woollacott (eds.). Microscopic Anatomy of Invertebrates. Vol.13. Lophophorates, Entoprocta, and Cycliophora. N.Y.: Willey-Liss. P.297-407.

Kocot K.M., Struck T.H., Merkel J., Waits D.S., Todt Ch., Brannock P.M., Weese D.A., Cannon J.T., Moroz L.L., Lieb B., Halanych K.M. 2017. Phylogenomics of Lophotrochozoa with consideration of systematic error // System. Biol. Vol.66. No.2. P.256-282.

Kuzmina T.V., Malakhov V.V., Temereva E.N. 2018. Ultrastructure of the lophophoral coelomic lining in the brachiopod Hemithiris psittacea: functional and evolutionary significance // Zoomorphology. Vol.132. No.2. P.257-272.

Mukai H., Terakado K., Reed C.G. 1997. Bryozoa // F.W. Harrison, R.M. Woollacott (eds.). Microscopic Anatomy of Invertebrates. Vol.13. Lophophorates, Entoprocta, and Cycliophora. NY: Willey-Liss. P.45-206.

Schwaha Th.F., Handschuh S., Ostrovsky A., Wanninger A. 2018. Morphology of the bryozoan Cinctipora elegans (Cyclostomata, Cinctiporidae) with first data on its sexual reproduction and the cyclostome neuromuscular system // BMC Evol. Biol. Vol.18. P.1-28.

Schwaha T.F., Wanninger A. 2015. The serotonin-lir nervous system of the Bryozoa (Lophotrochozoa): a general pattern in the Gymnolaemata and implications for lophophore evolution of the phylum // BMC Evol. Biol. Vol.15. No.223. doi:10.1186/s12862-015-05089 (2015).
Schwaha T., Wood T.S. 2011. Organogenesis during budding and lophophoral morphology of Hislopia malayensis Annandale, 1916 (Bryozoa, Ctenostomata) // BMC Dev. Biol. Vo.11. No.1:23.54

Temereva E.N. 2015. Organization of the coelomic system in Phoronis australis (Lophotrochozoa: Phoronida) and consideration of the coelom in the lophophorates // J. Zool. Vol.296. No.2. P.79-94.

Temereva E.N. 2017. Morphology evidences the lophophorates monophyly: brief review of studies on the lophophore innervation // Invert. Zool. Vol.14. No.1. P.85-91.

Temereva E.N. 2017a. Innervation of the lophophore suggests that the phoronid Phoronis ovalis is a link between phoronids and bryozoans // Sci. Rep. Vol.7. No.1440. P. 1-16.

Temereva E.N. 2017b. Ultrastructure of the coelom in the brachiopod Lingula anatina // J. Morphol. Vol.278. P.997-1011.

Temereva E.N., Kosevich I.A. 2016. The nervous system of the lophophore in the ctenostome Amathia gracilis provides insight into the morphology of ancestral ectoprocts and the monophyly of the lophophorates // BMC Evol. Biol. Vol.16. No.181. P.1-24.

Temereva E.N., Kosevich I.A. 2018. The nervous system in the cyclostome bryozoan Crisia eburnea as revealed by transmission electron and confocal laser scanning microscopy // Front. Zool. doi: 10.1186/ s12983-018-0295-4.

Temereva E.N., Kuzmina T.V. 2017. The first data on the innervation of the lophophore in the rhynchonelliform brachiopod Hemithiris psittacea: what is the ground pattern of the lophophore in lophophorates? // BMC Evol. Biol. Vol.17. No.172. P.1-19 doi: 10.1186/ s12862-017-1029-5.

Temereva E.N., Tsitrin E.B. 2014. Development and organization of the larval nervous system in Phoronopsis harmeri: new insights into phoronid phylogeny // Front. Zool. Vol.11. No.1:3.

Temereva E.N., Tsitrin E.B. 2015. Modern data on the innervation of the lophophore in Lingula anatina (Brachiopoda) support the monophyly of the lophophorates // PLoS ONE Vol.10. No.4. e0123040.

Weber A.V., Wanninger A., Schwaha T.F. 2014. The nervous system of Paludicella articulata - first evidence of a neuroepithelium in a ctenostome ectoproct // Front. Zool. Vol.11. No.89. doi:10.1186/s12983014-0089-2.

Responsible editor K.G. Mikhailov 